\title{
Constitutional Basis for the Civil Rights of Illegitimate Children
}

\author{
Bernadeta Resti Nurhayati \\ Faculty of Law and Communication, Soegijapranata Catholic University \\ Jln. Pawiyatan Luhur IV/No. 1, Bendan Duwur, Semarang, 50247, Indonesia \\ Tel./Fax: +62-24-8441555,_E-mail: bernadeta_resti@yahoo.com
}

\begin{abstract}
The specification of children into "legitimate children" and "illegitimate children" is well-known legally and socially. Illegitimate children suffer discrimination because of their status. In law, they only have their mothers and mother's family. Although there has been a Constitutional Court Decision No. 046 / PUU-VIII / 2010, but it does not automatically raise the dignity of illegitimate children. On the other hand Law No. 24 of 2014 has made the children who were not born from a marriage by religion lose their rights to be recognized. This paper was aimed to find the constitutional basis for the civil rights of illegitimate children as the basis to provide the civil rights for illegitimate children so that their civil rights are protected.The method used in this paper was normative.Based on the review, there is a constitutional basis to provide the protection to the civil rights of illegitimate children.
\end{abstract}

Keywords: illegitimate children; constitutional basis; civil rights

\section{INTRODUCTION}

In societies, the children born out of legitimate marriage are still found. The birth of children out of wedlock happened because their parents got married only by religion (siri marriage). Another possibility is that the children are the results of a crime (rape), or even both their parents are not bound in a marriage at all. Freedom of association easily makes people do things which are not deservedly performed by people who are not bound in matrimony. It is not in accordance with the Indonesian's cultural values and morality recognized in Indonesian society.

In peopole's daily association, children born out of wedlock experience social discrimination in the form of ridicule from the people because they were born out of a relationship deemed illegitimate according to the value and capacity of the local community. The community gives the nicknames to several terms, such as "anak haram jadah", "anak kampang", "anak sumbang", "anak kowar", "anak astra" and so forth. The 
nickname is the stigma that would be a bad experience for the children during their lives. The children become the object of scorn from friends who believe that the children born out of wedlock can bring a havoc to the surrounding environment. The psychological impact of the boos and jeers will be left in the memory of the children until they grow up.

By law, illegitimate children also suffer discrimination. They only have a civil relationship with their mothers and mother's family. The judicial review of Article 43 paragraph (1) in conjunction with Article 2 paragraph (1) and (2) of Law No. 1 of 1974 on Marriage was decided by the Constitutional Court through the Constitutional Court Decision Number 046 / PUU-VIII / 2010. It is not automatically change the provisions of Article 43 paragraph (1) of the Marriage Law. This means that illegitimate children do not necessarily have a civil relationship with their biological fathers and biological father's family. The mother or children concerned must apply the legal effort in an advance to get their rights.

The consequenceto have a civil relationship only with their mother and mother's family is that illegitimate children only have the right to care, right to education, and right to inherit from their mothers and mother's family. Illegitimate children are then, as if, apart from a relationship with their biological fathers. Biological father, by law, is exempt from the obligation to be responsible, nurture, and educate his own children.

In the system of the Indonesian Civil Code (KUHPerdata), there are two institutions which are intended to build a civil relationship with parents. The institutionsarethe institution of "child recognition " and the institution of "legitimation of illegitimate children".

Regarding the definition of "child recognition", J. Satrio argued that: "the recognition is a statement containing the recognition that the person concerned is the father or mother of anillegitimate children recognized by them." ${ }^{1}$ In the draft of the Indonesian Civil Code, illegitimate childrendo not have a relationship with anyone, neither their father nor mother. Therefore, their biological mothers and fathers still have to do the recognition of children born out of wedlock. The recognition performed by the father and/ or mother that provides the civil rights to illegitimate children. According to D.Y. Witanto, recognition in the Indonesian

1 J. Satrio. (2000). Hukum Keluarga tentang Kedudukan Anak dalam Undang-Undang. Bandung: Citra Aditya Bakti, pg. 109 
Civil Code system is referred to as an absolute recognition. $^{2}$

Legitimation, according to Subekti, is a further action of recognition. Legitimation is only possible when both parents are married after they recognize their children. Recognition and legitimation can be performed simultaneously with the solemnization of their marriage. With the legitimation, illegitimate children obtain the same position as well as the legitimate ones in a marriage. $^{3}$

In subsequent development, when Law No. 1 of 1974 on Marriage was enacted, the aid institution for illegitimate children is not regulated. In Article 43 paragraph (1) of Marriage Law, it only stipulates that children born out of wedlock only have civil relationship with their mothers and mother's family. In other hand, Article 43 paragraph (2) promises that the Government would set about illegitimate children in a separate government regulation. However, until

2 The recognition in the system of the Indonesian Civil Code is called "absolute recognition", in which an illegitimate child does not have a civil relationship with his/ her father and/ or mother without their recogition. Compare with D.Y. Witanto. (2012). Hukum Keluarga, Hak dan Kedudukan Anak Luar kawin Pasca Keluarnya Putusan MK tentang Uji Materiil UU Perkawinan. Jakarta: Prestasi Pustaka, pg. 45-46

3 R. Subekti.(1990). Ringkasan tentang Hukum Keluarga dan Hukum Waris. Jakarta: PT. Intermas, pg. 14. recently, the Government Regulation referred to it has not been enacted.

The absence of regulation other than the Civil Code makes the implementers in the field use the Civil Code as the legal basis in recording child recognition and legitimation to illegitimate children. ${ }^{4}$ It can be understood in order to avoid a legal vacum.

With the enactment of Law No. 23 2006 on Administration and Population, the issue of the procedures for child recognition and legitimation for illegitimate children has been answered. This law regulates the registration procedure in Article 49 and the child recognition and legitimation under Article 50. In principle, against illegitimate children, the recognition by their biological fathers may be performed provided they meet two conditions: (1) approved by the child's biological mother, (2) his/ her religion justify/ allow the recognition of the children born out of legal marriage relationship. For the information, there is a religion that does not allow the legitimation for illegitimate children are considered as the child of adultery.

\footnotetext{
4 An interview session with the Head of Civil Registration Section of the Population and Civil Registration Agency of Semarang City, May 2016.
} 
According to Article 50 of Law No. 23 of 2006, child legitimation can be conducted if: (1) both parents have been legally married to the laws of religion and state. In order that a marriage is legal under the state law, the marriage must be recorded by the civil registry clerks or the employees of marriage, divorce, and reconciliation registrar; (2) The parents' religion does not justify the legitimation of the children born out of legitimate marriage. The legitimation shall be reported to the Civil Registration Officers so that their marriage has the legal consequences for the children born earlier.

The enactment of Law No. 24 of 2013 on the amendment of Law No. 23 of 2006 on Population and Administration has led to illegitimate children lose the right to recognition if both parents are not married religiously when they were born. They also lose the right to be legalized in the marriage of their fathers and mothers. The losing of the right to be recognized and legitimated is detrimental to the interests of illegitimate children .

This paper is not the first one discussiong illegitimate children. Muhammad Ridwansyah in his article titled "The Livelihoods of Illegitimate Children According to Al-Nafs Hifzhu
Concept" ${ }^{15}$ studied the Constitutional Court Decision No. 046 / PUU-VIII / 2010 and found that there are conformities between the theory of hifzhu al-nafs in mawashid syari'ah and the provisions of Article 43 paragraph (1) of Marriage Law, by shifting the responsibility of the father or the father's family by DNA test results to the living of illegitimate children. It is the purpose which is strongly supported by maqashid syari'ah because it ensures public benefit. ${ }^{6}$

This paper examined the presence of the legal basis in the Indonesian constitution as a link to provide legal protection to illegitimate children who lose the right to be recognized and legitimated by Law No. 24 of 2013. The constitutional foundation is esssential to explore given the application of the principle of lex superiori derogate legi inferiori based on the hierarchy that lower law must not conflict with the the higher law or with the Constitution of the State.

When the law aims to provide justice, expediency, and certainty of law against any legal subject, the children born out of wedlock should also be able to get their civil rights, especially from their biological fathers. This is why the writer

5 Muhammad Ridwansyah. (2012). Nafkah Anak Luar Kawin Menurut Konsep Hifzhu Al-Nafs. Jurnal Yudisial, 8 (1): 1 April 2015. 65-83.

${ }^{6}$ Ibid.pg. 82. 
was interested in studying the basis of the constitution to find the legal protection for illegitimate children to form a civil relationship with their biological mothers and fathers.

\section{METHOD}

This study used the method of normative. It is called juridical-normative because this paper was aimded to explore the principles of law to solve the problems that would be studied in this paper. The data used was secondary data, in the form of an inventory of positive legal norms in force in Indonesia governing the civil rights of illegitimate children and children's rights. The data was analyzed using qualitative analysis.

\section{ANALYSIS AND DISCUSSION \\ Some Cases in Indonesia}

Pregnancy is a natural event. It occurs because there is a meeting between ovum and spermatozoa. The meeting could take place naturally with the onset of sexual intercourse between a man and a woman. This is irrespective of whether the pregnancy is desired by both parties or unwanted pregnancy. Pregnancy may also occur intentionally/ artificial. Naturally, it is unlikely a woman can be pregnant without fertilization ${ }^{7}$. In the legal and

\footnotetext{
7 Compare with the Opinion of the Constitutional Court of the Republic of Indonesia in "Decree Number
}

society system in Indonesia, children born out of wedlock were resulted from an indecent relationship by those who are not tied up in a legal marriage.

One of the cases concerning illegitimate children recognition issues was the case of a singer who comes from East Java named TK. The case was sticking in the media at the beginning of January 2015. TK admitted that she has a child from her relationship with AS who has a wife. According to TK, when finding that TK was pregnant, AS told her to have an abortion, but TK refused and chose to keep her baby. During pregnancy through childbirth, AS never visited or provided a living. TK did not demand to a marriage, but she only struggled to get the recognition for the children born from the relationship in order to save her son's future. ${ }^{8}$

The case which also seized public attention was the case of MM. This case arose from a sirri marriage between MM and S. From the sirri marriage, a boy named MIR was born. The marriage was not recorded, so the child born from the marriage did not get the attention of $\mathrm{S}$ and

46/PUU-VIII/2010 on Marriage on the 1945 Constitution. Jakarta: the Constitutional Court of the Republic of Indonesia, pg. 43 from:

8 Kapanlagi.com. (2015). Selebriti. Available http://www.kapanlagi.com/showbiz/selebriti/d7b275.html /, access on February 17, 2015 
his family. When S died, MIR as the child did not inherit at all. MM as the sirri wife of the late $S$ filed a suit of MIR recognition as the son of the late $S$.

\section{Marriage Legality According to Indonesian Legal System}

According to the Marriage Law, marriage is legitimate when it fulfills the provisions of Article 2, which states:

(1) A marriage is legal when it is held according to the laws of religion and belief.

(2) Every marriage is recorded in accordance with the appllicable laws.

Under the provisions of Article 2 (1), a marriage is legitimate when it is held according to the laws of the couple's religion or belief. In the Indonesian legal system, there is no marriage out of religious legal system. Article 2 paragraph (2) requires that a marriage should be listed in the Marriage Registration Office. Thus, there are two requirements for a legitimate marriage, i.e.: (1) it complies with the law, and (2) it is listed in Marriage Registration Office. The sytem is different from the procedures of marriage in the Indonesian Civil Code. Regarding marriage procedures, Article 76 of the Civil Code provides that:

A marriage is legitimate when it takes place in public, in a building where the deed of civil registration must be made before an employee of the Civil Registration, in the domicile of one of the two parties, and in the presence of two witnesses, both family and non-family, who have reached the age of twenty-one years old and live in Indonesia.

In fact, Article 81 of the Civil Code specifies that religious ceremonies should not be made before a marriage in the presence of the Empoyee of the Civil Registration has been held. This is the proof that the Indonesian Civil Code separates legal and religious affairs.

Until recently, legal experts are still in different views regarding the provisions of Article 2 paragraph (1) and (2) above. There are two well-developed opinions among academics and practitioners, i.e.:

1. The group argued that the legitimacy of a marriage is adequate when it is carried out under the provisions of Article 2 paragraph (1) of the Marriage Law, which is the fulfillment of the conditions and procedures set by their religion. Meanwhile, the registration of marriage is an administration matter. When it is not implemented, it does not affect the legitimacy of a marriage..

2. The group argued that Article 2 paragraph (1) and (2) of the Marriage Law is an integral and inseparable one 
and must be implemented in cumulative, not a separated and independent alternative. ${ }^{9}$

One of the figures who consider that marriage registration is only administrative is Sayuti Talib stating that:

Yet, recording is not something that determines whether a marriage is legal or illegal. A marriage is legitimate when it is held in accordance with the provisions of their respective religions, even if it is not registered. ${ }^{10}$

Talib's outlook is in line with the Decree of the High Islamic Court, which in 1953 issued a decree (SK) No. 23/19 which stipulates that if the requirements of marriage are complete, but it is not registered, the marriage is legitimate. On other hand, the corresponding person is fined for not registering the marriage ${ }^{11}$. Gatot Supramonojuga said that the obligation of marriage registration is an administrative obligation. The problem is that the children born in an unregistered marriage are included into the group of "illegitimate children". The other cause of the birth of illegitimate children is that the

9 Abdul Manan. (2006). Aneka Masalah Hukum Perdata Islam di Indonesia. Jakarta: Kencana Prenada Media Group, pg. 49

10 Sayuti Thalib. (1986). Hukum Kekeluargaan Indonesia Berlaku Bagi Umat Islam. Jakarta: University of Indonesia (UI-Press), pg. 71

${ }^{11}$ H. Bakry dalam SayutiThalib. ibid father and mother are not married so that the children is truly not born in or as a result of a legal marriage. ${ }^{12}$

\section{The Institutes for Child Recognition and} Legitimation of Illegitimate Children

It has been mentioned in the introduction that the Indonesian Civil Code provides two institutions to assist illegitimate children to have civil relationships with their biological mothers and fathers. Both institutions are still being used as a material law in the practice of child recognition and legitimation of illegitimate chidlren at the Civil Registration Office to fill a legal vacuum.

However, in the next stage, when the Indonesian government enacted Law No. 23 of 2006 on Population and Administration, the discrimination has begun to be felt. The law regulates child recognition in Article $49^{13}$. This regulation begins to waive the right to be recognized and to recognize based on religious conditions. Thus, the illegitimate children, due to their parents' religions which do not permit the recognition, can not be recognized.

The waiver of the right to be recognized is getting more and more apparent in Law No. 24 of 2013 on the

\footnotetext{
12 Gatot Supramono. (1998). Segi-Segi Hukum Hubungan Luar Nikah. Jakarta: Djambatan, pg. 8

13 Read article 49 of Law No. 23 of 2006 on
} Administration and Population 
amendment of Law No. 23 of 2006 on Population and Administration. It is as mentioned in Article I Item 10 of Law No. 24 of 2013, which reads as follows:

(1) Child recognition shall be reported by the parents to the Executing Agency no later than 30 (thirty) days from the date of the child recognition by the father and approved by the child's mother.

(2) Child recognition applies only to the child whose parents hold a legal marriage by their religion, but not legal under state law.

(3) Based on the report referred to in paragraph (1), a Civil Registry officials notes on the register certificate of child recognition and issues the exerpt of child recognition certificate.

The amendment to the Population and Administration Law is increasingly apparent to limit the right to recognize and to be recognized. The children born out of wedlock who were born when their parents were not married by religion can not be recognized.

\section{Indonesia (as) a Welfare Law State}

Indonesia is a state of law. It is expressly stated in Article 1 (3) of the 1945 Constitution which states: "Indonesia is a state of law".
The notion on the State of Law had begun centuries ago, long before humans think of state and legal affairs, and a number of high civilizations were born. However, according to $\mathrm{H}$. Juniarso Ridwan and Achmad Sodik, the thought or awareness on state matters and such a law does not automatically cause a form of consciousness on state affairs. The existence of a state is prior to the existence of law. ${ }^{14}$

According to Tahir Azhari, in embryotic, the idea of state of law is put forward by Plato when he wrote his third work of "Nomoi". In the two previous works, "Politeia" and "politicos", there had no term of state of law. In Nomoi, Plato argued that good governance is based on good regulation (law). ${ }^{15}$ The view of Plato was continued by his pupil, Aristotle, who wrote a book "Politica". According to Aristotle, a good country is a country governed by constitution and sovereign of law. ${ }^{16}$

In the early stages of its development, the definition of state of law is a state having the duty to protect its citizens, or also called nachtwakerstaat

\footnotetext{
${ }^{14}$ H. Juniarso Ridwan dan Achmad Sodik. (2013). Tokoh-Tokoh Ahli Pikir Negara dan Hukum dari Zaman Yunani Kuno sampai Abad ke-. Bandung: Nuansa Cendekia, pg. 11

15 Tahir Azhary. (1992). Negara Hukum. Jakarta: Penerbit Bulan Bintang, pg. 66

${ }^{16}$ Tahir Azhary. (1995). Negara Hukum Indonesia. Jakarta: UI-Press, pg. 20-21
} 
(night-watch state). According to Wirjono

Prodjodikoro, the emergence of the school of welfare state is a further development of the school of night-watch state (Nachtwakerstaat). This view leaves the old-fashioned view that sees the State with its equipment only serving to keep the members of its community in everyday life not to fight and the relationships among the members of the community to run in an orderly manner ${ }^{17}$.

In line with Wiryono Prodjodikoro's view above, Miriam Budiharjo said that the Welfare State is also often called "State of Material Law ", which is a country whose government is not only responsible for the maintenance of public order and safety, but it is also responsible for the welfare of the society. ${ }^{18}$ In the type of State of Material Law, the organization of state government is based on law and justice with the purpose to create a governance that reflects the values and sense of public justice. $^{19}$

In the 19th century, Frederich Julius Stahl pointed out that the concept of state of law (rechtsstaat) is characterized by four basic elements, i.e.:

\footnotetext{
17 Wirjono Prodjodikoro. (1969). Asas-Asas Ilmu

Negara dan Politik. Bandung: Eresco, pg. 15
${ }_{18}$ Miriam Budihardjo. (1980). Masalah Kenegaraan,

${ }^{18}$ Mira dan Politik. Bandung: Eresco, pg. 15
Budihardjo. (1980). Masalah Kenegaraan, Jakarta: PT. Gramedia, pg. 74

${ }^{19}$ Nurul Qomar. (2014). Hak Asasi Manusia dalam Negara Hukum Demokrasi. Jakarta: Sinar Grafika, pg. 63
}

Pattimura Law Journal Vol.1 Issue 2, March 2017 | 126
1) Recognition and protection to human rights;

2) Separation or division of powers to guarantee those rights;

3) The government is organized under laws (wet-matig van bestuur); and

4) The administration judiciaty in dispute. $^{20}$

In a state of law, law is placed as the rules in the administration of a state, government, and social affairs. In other hand, the purpose of law is aimed to organize a peaceful, fair, and meaningful society. It means that the target of state of law is the achievement of state, government, and social activities which is based on justice, peace, and usefulness or meaningfulness. Therefore, a state needs to intervene in some specific concerns, such as child, woman, worker, and refugee protection matters,. In terms of children's affairs, for example, children do not have the power to protect and help themselves, but they require the state or at least adult intervention.

\section{The Constitutional Basis for the Civil Rights of Illegitimate Children}

In the 19th century, Frederich Julius Stahl pointed out that the concept of state of law (rechtsstaat) is characterized by four basic elements, i.e.:

20 Miriam Budiharjo. (2008). Dasar-Dasar Ilmu Politik. Jakarta: Gramedia Pustaka Utama, pg. 57. 
1) Recognition and protection to human rights;

2) Separation or division of powers to guarantee those rights;

3) The government is organized under laws (wet-matig van bestuur); and

4) The administration judiciaty in dispute. $^{21}$

The four essential elements as mentioned by Stahl are still relevant today and as the to indicators to be called as a welfare state. The four elements are also found/ discovered in Indonesia as welfare state. Indonesia has stated explicitly that Indonesia is a state of law. ${ }^{22}$ This brings the consequence that the country will make every effort for the welfare of its citizens, both in law and in everyday life.

One element of a state of law, according to Stahl, is the implementation of Government under laws. In Indonesia, it is met since the Constitution is the basis to run the government, including in the matter of the protection to illegitimate children.

In relation with the protection to the civil rights of illegitimate children, in 1945 Constitution, there are several articles that constitute the constitutional basis, i.e.:

\section{Article 1 paragraph (3) states: \\ "Indonesia is a state of law."}

\footnotetext{
${ }^{21}$ Ibid

${ }^{22}$ In article 1 paragraph (3) of th 1945 Constitution. This article is the result of the third amendment to the 1945 Constitution which was held in the period of 9 November 2001 - 10 August 2002.
}

The statement concerning Indonesia's status as a state a law firmly brings the consequence that the state should accomplish people's welfare without exception.

2. Article 28B paragraph (1) states: "Anyone has the right to make a family and continue the descent through a legal marriage."

3. Article 28B paragraph (2) states: "Any child has the right to live, grow, and develop as well as the right to protection from violence and discrimination.

4. Article 28D paragraph (1) states: "Anyone has the right to recognition, security, protection and legal certainty and equal treatment before the law."

The constitutional basis as described above has been implemented in the practice of the state administration through the enactment of various laws enacted after the amendments to the 1945 Constitution. The amendment stages of the four paragraphs can be described as follows: 
Table 1.

The Time of the Amandemen Implementation $^{23}$

\section{No Article/paragraph Amendments}

\begin{tabular}{|c|c|c|}
\hline 1 & $\begin{array}{l}\text { Article } 1 \text { paragraph } \\
\text { (3) }\end{array}$ & $\begin{array}{ll}\text { Third } & \text { Amendment } \\
\text { on } 9 & \text { November } \\
2001 & \end{array}$ \\
\hline & $\begin{array}{l}\text { Article 28B } \\
\text { paragraph (1) }\end{array}$ & $\begin{array}{l}\text { Second Amendment } \\
\text { on } 18 \text { August } 2000\end{array}$ \\
\hline & $\begin{array}{l}\text { Article 28B } \\
\text { paragraph (2) }\end{array}$ & $\begin{array}{l}\text { Second } \\
\text { Amendment on } 18 \\
\text { August } 2000\end{array}$ \\
\hline & $\begin{array}{l}\text { Article 28D } \\
\text { paragraph (1) }\end{array}$ & $\begin{array}{l}\text { Second } \\
\text { Amendment on } 18 \\
\text { August } 2000\end{array}$ \\
\hline
\end{tabular}

After the second and third amendments were implemented by the Government, there are several laws in the field of the protection to the child's civil rights, i.e.:

1. Law No. 23 of 2002 on Child Protection;

2. Law No. 23 of 2006 on Population and Administration;

3. Law No. 24 of 20013 on the Amendment of Law No. 23 of 2006 on Population and Administration;

4. Law No. 35 of 2014 on the amendment of Law No. 23 of 2002 on Child Protection.

\footnotetext{
23 Sistem Pemerintahan Negara Indonesia. blogspot.co.id. (2017). Available from: http://sistempemerintahannegaraindonesia.blogspot.co.id/ 2016/01/hasil-amandemen-uud-1945-dantahapannya.html, access on March 17, 2017
}

Nevertheless, it should also be understood that sometimes the 1945 Constitution and the laws, or between one law and the others, are less synchronous/ lack of harmony. The unsynchronized relationship occurs between the 1945 Constitution and Law No. 24 of 2013, in particular in Article I point 10 and point 11.

The provisions of Article I point 10 and point 11 of Law No. 24 of 2013 lead to the loss of the rights of children born out of wedlock (born before the religious marriage of both parents) to get their fathers' approval or legitimation because both parents are legally married. Meanwhile, every child has the rights to survival, growth and development. Each child also has the right to recognition, security, protection and equal standing before law. The loss of the right to be recognized and approved is contrary to the constitutional rights of illegitimate children.

Citing the Constitutional Court's view, the legislation should not negate the responsibility of man and woman who have caused the birth of a child as father and mother in which the responsibilities are attached to both. ${ }^{24}$ Therefore, based on the above provision, Article I point 10 and

\footnotetext{
${ }^{24}$ Read Mahkamah Konstitusi. (2012). op.cit.
} 
point 11 of Law No. 23 of 2013 should be revised to open up the opportunities for the recognition by biological fathers, by removing the requirements as mentioned above.

\section{CONCLUSION}

Based on the foregoing description above, it can be concluded as follows::

1. There are several articles in the 1945 Constitution, which are relevant as the constitutional basis for the protection to the civil rights of illegitimate children, such as Article 1 (3), Article 28B paragraph (1) and (2), Article 28D paragraph (1). The constitutional basis is the basis for the regulations in laws as the implementing regulations of the 1945 Constitution.

2. Law No. 24 of 2013 has eliminated the right to be recognized and legitimated of illegitimate children who were born before their parents are married by religion law. This requirement complicates illegitimate children to form the civil relationship with their biological fathers.

3. The Government shall protect illegitimate children including their civil right protection by revising Law No. 24 of 2013 to restore the rights to be recognized and legitimated for ilegitimate children without exception.

\section{BIBLIOGRAPHY}

Abdul Manan. (2006). Aneka Masalah Hukum Perdata Islam di Indonesia. Jakarta: Kencana Prenada Media Group.

D.Y. Witanto. (2012). Hukum Keluarga, Hak dan Kedudukan Anak Luar kawin Pasca Keluarnya Putusan MK tentang Uji Materiil UU Perkawinan. Jakarta: Prestasi Pustaka.

Gatot Supramono. (1998). Segi-Segi Hukum Hubungan Luar Nikah. Jakarta: Djambatan.

H. Juniarso Ridwan dan Achmad Sodik. (2013). Tokoh-Tokoh Ahli Pikir Negara dan Hukum dari Zaman Yunani Kuno sampai Abad ke-20. Bandung: Nuansa Cendekia.

HR. Ridwan. (2014). Hukum Administrasi Negara, Edisi Revisi, Jakarta: PT. Raja Grafindo Persada.

J. Satrio. (2000). Hukum Keluarga tentang Kedudukan Anak dalam UndangUndang. Bandung: Citra Aditya Bakti.

Mahkamah Konstitusi. (2012). PutusanNomor 46/PUU-VIII/2010 tentangPerkawinanterhadapUndangUndangDasar Negara Republik Indonesia Tahun 1945. Jakarta: Mahkamah Konstitusi Republik Indonesia.

Miriam Budihardjo. (1980). Masalah Kenegaraan, Jakarta: PT. Gramedia. Gramedia Pustaka Utama.

Muhammad Ridwansyah. (2012). "Nafkah Anak Luar Kawin Menurut Konsep Hifzhu Al-Nafs". Jurnal Yudisial, 8 (1): 1 .

Nurul Qomar. (2014). Hak Asasi Manusia dalam Negara Hukum Demokrasi (Human Rights in Democratiche Rechtsstaat), Jakarta: Sinar Grafika. 
R. Subekti.(1990). Ringkasan tentang Hukum Keluarga dan Hukum Waris. Jakarta: PT. Intermasa.

Sayuti Thalib. (1986). Hukum Kekeluargaan Indonesia Berlaku Bagi Umat Islam. Jakarta: Universitas Indonesia (UI-Press).

Tahir Azhary. (1992). Negara Hukum, Jakarta: Penerbit Bulan Bintang.

Tahir Azhary. (1995). Negara Hukum Indonesia. Jakarta:UI-Press.

Wirjono Prodjodikoro. (1969). Asas-Asas Ilmu Negara dan Politik, Bandung: Eresco.

\section{Website:}

World Wide Web:Kapanlagi.com. (2015). Selebriti. Available from: http://www.kapanlagi.com/showbiz/s elebriti/d7b275.html/. [Accessed February 17, 2015]. 